Article

\title{
Impacts of U.S. Carbon Tariffs on China's Foreign Trade and Social Welfare
}

\author{
Wenwen Zhang ${ }^{1}$, Shichun $\mathrm{Xu}^{2, *} \mathbb{0}$, Zhengxia He ${ }^{3, *}$, Basil Sharp ${ }^{1}$, Bin Zhao ${ }^{4}$ and Shuxiao Wang ${ }^{5}$ \\ 1 Energy Center, University of Auckland, Auckland 1010, New Zealand; \\ wenwen.zhang@auckland.ac.nz (W.Z.); b.sharp@auckland.ac.nz (B.S.) \\ 2 Management School, China University of Mining and Technology, Xuzhou 221116, China \\ 3 Business School, Jiangsu Normal University, Xuzhou 221116, China \\ 4 Pacific Northwest National Laboratory, Richland, WA 99352, USA; bin.zhao@pnnl.gov \\ 5 State Key Joint Laboratory of Environmental Simulation and Pollution Control, School of Environment, \\ Tsinghua University, Beijing 100084, China; shxwang@tsinghua.edu.cn \\ * Correspondence: xushichun@cumt.edu.cn (S.X.); hezhengxia1979@jsnu.edu.cn (Z.H.)
}

Received: 31 August 2019; Accepted: 24 September 2019; Published: 25 September 2019

check for updates

\begin{abstract}
A recursive multisector dynamic computable general equilibrium (DCGE) model simulates the economic impacts of carbon tariffs, as proposed by the USA, ranging from $\$ 40 / \mathrm{t}$ to $\$ 60 / \mathrm{t} \mathrm{CO}_{2}$. We examine a carbon tax and export subsidy as response policies to the U.S. carbon tariff, respectively. The dynamic model shows the possible impacts of these policies on China's economic structure, carbon emissions, and social welfare from 2020 to 2030. Simulations show that a carbon tariff changes the structure of China's exports and promotes trade diversion from the USA to other countries and regions. A domestic carbon tax and subsidy policy can dampen the adverse impacts of carbon tariffs on trade. A carbon tax shows an effective impact on increasing clean energy use, decreasing the carbon intensity of output, and reducing carbon emissions. A subsidy on exports to the USA reduces the adverse impact of a carbon tariff on China's social welfare in the short term.
\end{abstract}

Keywords: carbon tariffs; response policy; carbon emissions; trade; energy structure

\section{Introduction}

In 2007, Chirac, the former French president, put forward the concept of "carbon tariffs". In 2009, the US House of Representatives passed the "American Clean Energy Security Act" of 2009 [1], resulting in a carbon tariff on imports from countries without a carbon emission reductions policy from 2020. Although this bill never made it to the Senate floor, U.S. would not need to be carbon motivated to impose additional tax on imports from China based on the recent "China-U.S. trade war". Actually, the U.S. has put forward "the Energy Innovation and Carbon Dividend Act", which can be taken as carbon tariffs. Carbon tariffs are likely to impact economic structure and trade patterns, especially for developing countries that export carbon intensive goods.

China, the largest developing country, has overtaken the U.S. to be the biggest carbon emitter since 2007. In recent years, the frequent occurrence of smog and extreme weather has made society aware of the importance and urgency of low-carbon development. Therefore, China is still exploring an emission reduction policy to deal with environmental issues caused by rapid industrialization and urbanization. As an important trading partner, the total export-import volume between China and the U.S. in 2017 is more than $\$ 583.68$ billion, accounting for $14.21 \%$ of China's total trading. Therefore, the impacts of the U.S. trade policy on China should not be underestimated. Therefore, how to formulate appropriate response policies to the U.S. carbon tariff is an urgent problem.

The Computable General Equilibrium (CGE) model, based on the general equilibrium theory of Walras [2], describes the relationship between the supply, demand, and price of the entire economy 
framework. It is driven by the price mechanism to investigate the influence of an exogenous disturbance on the economic system and other economic variables under the transition from one equilibrium state to another. At present, the CGE model has been popularly applied for policy analyses involving economy and trade, climate change, tax reform, energy conservation, and so on. A recursive dynamic CGE model, compared to the static model, has the advantage that it can study the accumulated effect for policy simulation. Therefore, this paper uses a multisector dynamic CGE model to simulate the effects of U.S. carbon tariffs on China's economic structure, carbon emissions and social welfare from 2020 to 2030. We provide the results of implementing a domestic carbon tax and export subsidy as possible responses to a carbon tariff. The paper is organized as follows. Section 2 presents a brief literature review. Section 3 introduces the CGE model and the data sources. Section 4 introduces the model-based simulation results. Further discussion is presented in Section 5. Finally, Section 6 presents conclusions and policy recommendations.

\section{Literature}

To discourage emission leakage and unfair competition aroused by different carbon emission level worldwide, Rocchi et al. [3] simulated carbon tariffs applied by the European Union (EU) based on avoided emissions and embodied emissions, respectively. The comparison of results suggests that carbon tariffs based on avoided emissions would have a smaller impact on most of the countries, especially on developing countries. However, there is a big debate on the legality of carbon tariffs. From the qualitative perspective, Shen [4] analyzed the legality of carbon tariffs based on all the aspects of the principle of multilateral environmental convention, the fundamental principles and the environment exception clause of the WTO, as well as its dispute settlement practice, and found that carbon tariffs levied by the USA are inconsistent with multilateral laws. From a quantitative perspective, Lin and Li [5] applied a multination CGE model and found that carbon tariffs will be unreasonable from the four perspectives of welfare, competitiveness, national output, and carbon emissions. Studies on potential impacts of carbon tariffs, in recent years, have been explored. Dong and Whalley [6] built a multiregional CGE model to investigate the impacts of the EU's and US's carbon tariffs on China, and they found that carbon tariffs will be negative to China's economy. Carbon tariffs also show to adversely impact other developing economies, such as Brazil and India $[7,8]$. Wu and Wang [9], when building a CGE model, found that the negative effects of the U.S. carbon tariffs will extend to all industries, but highly focused on smelting and pressing of ferrous metals and the mining and washing of coal. Majocchi and Missaglia [10], using a CGE model to simulate the carbon emission reduction effect of carbon tariffs, found that carbon tariffs can effectively improve the environment of the 15 member countries of the EU without negative effect on economy. They concluded that carbon tariffs can achieve "double dividend" (better environment, less economic loss). However, some research finds the effect of carbon tariffs on reducing global emissions to be small (e.g., Hübler [11]; Fischer and Fox [12]). Kuik and Hofkes [13] built a multisector and multiregion CGE model to examine the impact of carbon tariffs in the EU emission trading scheme (ETS) market, and found that carbon tariffs might reduce sectoral leakage rate forcefully, including the iron and steel industry, but the reduction of the macro leakage rate would be modest. Based on the results from above studies, there is still a large uncertainty in economic and environmental effects of carbon tariffs.

In addition, some other environmental policies have also been broadly explored, such as carbon taxation, ETS, energy taxation, and subsidy policies for renewable energy. The uniform conclusion in the current studies is that a carbon tax exhibits a superior mechanism for reducing carbon emissions (e.g., Xu and Zhang [14]; Xu et al. [15]). Zhang and Zhang [16], applying a CGE model, confirmed a remarkable impact of a carbon tax policy on carbon emissions and economic welfare in China's tourism industry. They also pointed out that the impacts of various carbon taxes on different sectors at different times would be quite diverse. A carbon tax contributes to a decline in worldwide welfare (Wesseh et al. [17]). Conclusions on economic effects of a carbon tax are mixed. Some authors argued that a carbon tax may slow down economic growth (e.g., Wei et al. [18]; Dong et al. [19]), 
whereas Lu et al. [20] and Liu and Lu [21] found that carbon taxes have a limited effect on economy. The economic and environmental impacts of ETS have been widely discussed. Zhang and Wei [22] and Zhang et al. [23] provided evidence that ETS is an important mechanism for reducing greenhouse gas emissions worldwide. Zhang et al. [24] and Wang et al. [25], based on the experience of seven pilots in China, found that ETS has a potential to increase economic growth. The EU Emissions Trading Scheme (EU ETS) as the largest multinational carbon market plays as significant role in slowing climate change. Martin et al. [26] reviewed the recent literature on the EU ETS, and they found that the EU ETS has a negative impact on carbon emissions, but empirical results cannot support that the EU ETS strongly diminishes the economy. From the perspective of micro firms, Oestreich and Tsiakas [27] explored the impact of the EU ETS on stock returns based on an empirical investigation. Their results show is a significant carbon premium in stock returns. In December 2017, the national ETS in China was firstly imposed on power production sector. Lin and Jia [28] based on a CGE model found that China's national ETS market is effective to reduce carbon emissions. The distributional effects of energy taxes levying on transport fuels, heating fuels and electricity are different [29]. Total factor productivity (TFP) can be influenced by changes in energy taxation [30]. Higher tax rate results in negative marginal effect on TFP [31]. Rocchi et al. [32] found that only little economic cost is caused by energy taxation in EU 27 countries. Energy tax can improve environment while cannot influence output level, which points to no existence in the double dividend effect of energy taxation [33]. Subsidy policies, to some extent, promote the development of renewable energy and bring environmental benefits [34]. The optimal subsidy to renewable energy is designed according to the project value and threshold value [35], while also maximizing the Government's expected policy benefits [36]. Murray et al. [37] focused on the possible largest subsidies for US renewable energy to explore the effect of GHG emissions abatement. Unfortunately, subsidies for renewable energy have very small effects on US GHG emissions.

However, considering that China's responses to carbon tariffs is seldom mentioned in the existing literature, Liang et al. [38], Dissou and Karnizova [39], Eyland and Zaccour [40], Dong et al. [41], and $\mathrm{Qu}$ and $\mathrm{Wu}$ [42] compared the different impacts of a carbon tariff and carbon tax, but did not take a carbon tariff as a response policy. However, the researches of Zhu [43] and Jiang [44] are similar to our study. They found that carbon tariffs would reduce China's GDP and welfare, and the effect of carbon emissions will be limited, but implementing a carbon tax would effectively cope with the threat of carbon tariffs. The game theoretic models of Yang and Wei [45], Zhan [46], and Hou et al. [47] show that export subsidies as a response policy to carbon tariffs could improve international competitiveness and the optimal rate of export subsidies should increase with the carbon tariff rate.

Although the effects of carbon tariffs on the economy and emission reduction have been studied several, shortcomings remain. First, few studies have considered China's response to a U.S. carbon tariff, such as a domestic carbon tax and export subsidy. The structural effects of carbon tariffs on trade, output and energy have yet to be extensively analyzed. Second, static CGE models by their very nature provide limited insights into the long-term effects of policy. Furthermore, the assumptions of some models deviate from reality, particularly the small country assumption used in the case of China. Studies that use game theory to study China's export subsidy policy rarely use CGE models.

\section{Methodology and Data Resources}

\subsection{Model Construction}

In order to fully study the long-term impacts of a carbon tariff, we construct a recursive DCGE model. The basic framework can be founded in Figure 1. There are 21 sectors, including 13 non-energy sectors (sector 1: Primary industry; sector 2: Mining industry; sector 3: Food manufacturing and tobacco processing industry; sector 4: Textile and products industry; sector 5: Wood-processing, paper, and printing industry; sector 6: Chemical industry; sector 7: Nonmetallic mineral production 
industry; sector 8: Metal smelting and production industry; sector 9: Machinery and equipment manufacturing; sector 10: Communications, instrumentation and other equipment manufacturing; sector 11: Construction; sector 12: Transportation, storage, and post; and sector 13: Other services) and eight energy sectors (sector 14: Coal mining and selection; sector 15: Coking industry; sector 16: Oil exploitation industry; sector 17: Oil and nuclear fuel processing industry; sector 18: Gas exploration industry; sector 19: Gas production and supply; sector 20: Thermal power; and sector 21: Clean energy). The basic consumptions and equations on the five modules of production, institutions, balance and closure, dynamics and welfare can be found in $\mathrm{Xu}$ et al. [48]. As a modification and extension, the other two modules—-trade and carbon tariffs—are specifically introduced as follows.

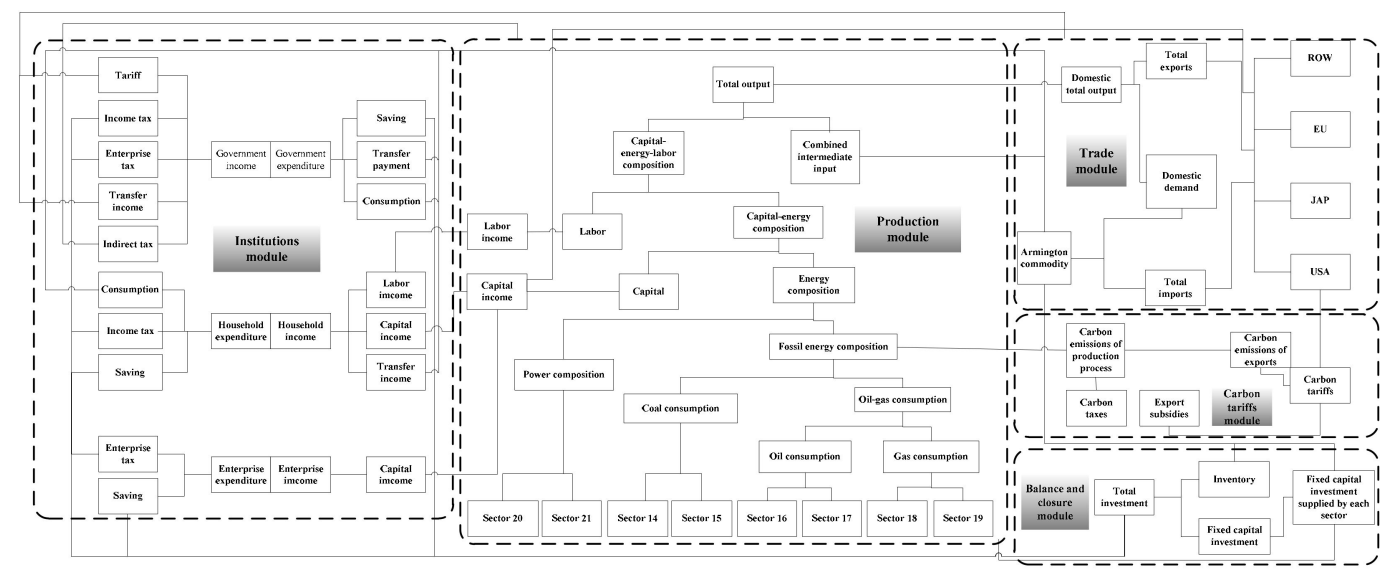

Figure 1. Basic framework of the dynamic CGE model.

\subsubsection{Trade}

In contrast to earlier studies, we assume that China can impact international prices [49], which is shown in Equations (1) and (2), where pwe $e_{c}$ and $Q E_{c}$ represent the world export price and exports, respectively; $p w e 0_{c}$ and $Q E 0_{c}$ are the corresponding initial values; $\rho_{a}^{Q Q}$ is the substitution elasticity parameter between demand for domestic production and imports; $p w m_{c}$ and $Q M_{c}$ represent the world import price and imports, respectively; $p w m 0_{c}$ and $Q M 0_{c}$ are corresponding initial values; and $\rho_{c}^{C E T}$ is the substitution elasticity parameter between demand for domestic production and exports; the subscript $c$ represents 21 commodities.

$$
\begin{gathered}
p w e_{c}=p w e 0_{c} \cdot\left(\frac{Q E_{c}}{Q E 0_{c}}\right)^{\frac{1}{1-\rho_{c} Q}} \\
p w m_{c}=p w m 0_{c} \cdot\left(\frac{Q M_{c}}{Q M 0_{c}}\right)^{\frac{1}{1+\rho_{c}^{C E T}}}
\end{gathered}
$$

The relationship between domestic consumption and imports follows a constant elasticity of substitution function (CES), and these two cannot be completely substituted, as shown in Equation (3). Where $Q Q_{c}$ is the commodity quantity in the domestic market; $Q D_{c}$ is the demand for domestic production; $P D_{c}$ is the corresponding price; $P M_{c}$ is the import price in local currency; $\alpha_{c}^{Q Q}$ and $\delta_{c}^{Q Q}$ are scale and share parameters, respectively.

$$
\begin{gathered}
\min \left(Q D_{c} \cdot P D_{c}+Q M_{c} \cdot P M_{c}\right) \\
\text { s.t. } Q Q_{c}=\alpha_{c}^{Q Q} \cdot\left(\delta_{c}^{Q Q} \cdot Q D_{c} \rho_{c}^{Q Q}+\left(1-\delta_{c}^{Q Q}\right) \cdot Q M_{c} \rho_{c}^{Q Q}\right)^{\frac{1}{\rho_{c}^{Q Q}}}
\end{gathered}
$$

Imports from USA, Japan (JAP), EU(The EU includes the UK in this study because the data were obtained before 2016), and the rest of the world (ROW) follow a CES function as shown in 
Equation (4), where $Q M s_{r, c}$ and $P M s_{r, c}$ denote China's imports from region $r$ and the corresponding price in local currency, respectively; $\alpha_{r, c}^{M}$ is the scale parameter; $\delta_{r, c}^{M}$ is the share parameter, $\sum_{r} \delta_{r, c}^{M}=1$; and $\rho_{c}^{M}$ is the substitution elasticity parameter between imports from different regions; the subscript $r$ represents four regions.

$$
\begin{gathered}
\min \sum_{r} Q M s_{r, c} \cdot P M s_{r, c} \\
\text { s.t. } Q M_{c}=\alpha_{r, c}^{M} \sum_{r} \delta_{r, c}^{M} \cdot Q M s_{r, c}^{\rho_{c}^{M}}
\end{gathered}
$$

In addition, gross domestic output allocated between exports and domestic goods is described by a constant-elasticity-of-transformation (CET) function, and exports to the USA, JAP, EU, and ROW are also described by a CET function.

\subsubsection{Carbon Tariffs}

Three ways are mainly used to calculate carbon emissions recently. Carbon emission coefficients from "Handbook of energy and economic statistics in Japan" are directly used to calculate carbon emissions [50]. Studies also use carbon emissions from each fuel combustion published in "International Energy Statistics" and data of fuel consumption to calculate emission coefficients. Different from these two methodologies, the Intergovernmental Panel on Climate Change (IPCC), based on carbon content of each fuel carbon, calculates emission coefficients (published in "Guidelines for National Greenhouse Gas Inventories") [51], which are more popular used in current studies. In this paper, we apply the third methodology. First, we transfer the unit of fossil fuels use from tonne ( $t$ ) to tonne coal equivalent (tce) based on the China's National Energy Statistic Book [52]. Then, we use the emission coefficients of six types of fuels obtained from the IPCC (2006) to calculate the carbon emissions ( EMCO2 $a$ ), as shown in Equation (5). To transfer the cost of carbon emissions to output, we use Equation (6) to represent carbon emissions per unit output $\left(\mathrm{Cem}_{\mathcal{c}}\right)$.

$$
\begin{gathered}
E M C O 2_{a}=\sum_{\text {fossil }=1}^{6}\left(Q E D_{\text {fossil }, a} \cdot a_{\text {fossil }} \cdot b_{\text {fossil }}\right) \\
\mathrm{Cem}_{c}=\sum_{a} \frac{E M C O 2_{a}}{Q A_{a}} \cdot \operatorname{sax}_{a, c}
\end{gathered}
$$

where $Q E D_{f o s s i l, a}$ is the energy consumption; $a_{f o s s i l}$ and $b_{f o s s i l}$ are the coefficients for converting energy into standard coal and carbon emissions, respectively; $\operatorname{sax}_{a, c}$ is a unit matrix; and fossil represents six fossil fuels.

Equation (7) describes the price changes of China's exports to the USA based on the carbon content of exports. It is assumed that the carbon tariff rate $(b c t)$ is levied on the carbon content of unit export to the USA. The price of exports to the USA ( $P E s_{c, u s a}$ ) adds an additional carbon emission cost, where EXR is the exchange rate.

$$
P E s_{c, u s a}+b c t \cdot C e m_{c} \cdot E X R=p w e_{c} \cdot E X R
$$

Equations (8)-(10) describe the China's carbon tax policy. We assume that a carbon $\operatorname{tax}\left(C T A X_{a}\right)$ is calculated by unit carbon emissions levied at $t c$, and the specific duties are converted to ad valorem duties, as shown in Equations (8) and (9). The carbon tax rate for each fossil fuel ( $\left.t_{\text {fossil }}\right)$ is calculated according to Equation (9). Thus, the equations in the sixth layer of the production module are adjusted by transforming every fossil fuel price from $P Q_{\text {fossil }}$ to $\left(1+t_{\text {fossil }}\right) \cdot P Q_{\text {fossil }}$. In addition, a carbon tax is added to government revenue ( $Y G$ ) as shown in Equation (10). Where $Q Q_{\text {fossil }}$ is the quantity of each fossil fuel in the domestic market; $P Q_{\text {fossil }}$ is the corresponding price; and TIND, TYH, TENT, Transfrgrow, and TIMP are the indirect tax, resident income tax, enterprise income tax, foreign transfer payments, and import tax, respectively.

$$
C T A X_{a}=t c \cdot E M C O 2_{a}
$$




$$
\begin{gathered}
t_{\text {fossil }}=\frac{t c \cdot \sum_{a}\left(Q E D_{\text {fossil }, a} \cdot a_{\text {fossil }} \cdot b_{\text {fossil }}\right)}{Q Q_{\text {fossil }} \cdot P Q_{\text {fossil }}} \\
Y G=T I N D+T Y H+T E N T+T I M P+\text { Transfrgrow } \cdot E X R+\sum_{a} C T A X_{a}
\end{gathered}
$$

An indirect subsidy for exports to the USA is provided by the Chinese government. As shown in Equation (11), the subsidy rate (esub) is directed at reducing the carbon tariff rate on exports to the USA, whereas the subsidy policy leads to increased government spending $(E G)$ in Equation (12). Where $P Q_{c}$ is the commodity price; $Q G_{c}$ is the government's commodity consumption; Transfrhg and $Y W G$ are transfer payments to households and foreign aid, respectively; and $Q E s_{c, u s a}$. denotes the quantity of exports to the USA.

$$
\begin{gathered}
P E s_{c, u s a}+(b c t-e s u b) \cdot \operatorname{Cem}_{c} \cdot E X R=p w e_{c} \cdot E X R \\
E G=\sum_{c} P Q_{c} \cdot Q G_{c}+\text { Transfrhg }+Y W G+\sum_{c} e s u b \cdot \operatorname{Cem}_{c} \cdot Q E s_{c, u s a} \cdot E X R
\end{gathered}
$$

\subsection{Data Sources and Parameter Setting}

A Social Accounting Matrix (SAM) is derived from China's input-output table of China Statistical Yearbook [53]. The 21 sectors were split and combined with China's extended input-output table. For example, the extraction of petroleum and natural gas was divided into oil exploitation industry and gas exploration industry based on their annual energy consumption ratios; production and supply of electric power and heat power was split into thermal power and clean energy based on their percentages of total power generation [52]. Household capital income, government transfer to residents, foreign transfer to residents came from the China Finance Yearbook [54]. Data regarding household savings, household income tax, and enterprise tax came from the China Finance Yearbook. Enterprise capital income was obtained using the row-sum and column-sum equality rule. Government tax income and savings were taken from the China Statistical Yearbook. Other data such as household labor income, the government consumption, and inventory fluctuation were from China's input-output table. The proposed capital gains and foreign saving of different countries and regions came from the China Customs Statistics Yearbook [55]), UNCOMTRADE database, and GTAP version 9 database statistics.

Endogenous parameters, such as share parameters for production functions, Armington functions, and CET functions, as well as transformation parameters, miscellaneous tax rates, and propensities to consume, were determined by calibration. Benchmark data from the SAM were used to calculate the unknown parameters. The exogenous parameters were obtained from previous studies $[50,56,57]$ and adjusted in our model, including the miscellaneous substitution elasticities, carbon emission factors, total factor productivity, and the rate of population growth. Some exogenous parameters, such as total factor productivity, were difficult to obtain, so we used the historical simulation method [58]. Standard coal conversion coefficients for fossil fuels and carbon emission coefficients were obtained from China's Energy Statistics Yearbook and the Guidelines for National Greenhouse Gas Inventories, respectively.

\section{Scenario Simulation Results}

As shown in Table 1, we examined the economic impacts of three fiscal policies. (1) Single carbon tariffs policy. In Scenarios 1-1 to 1-3, a carbon tariff is implemented by the USA on the carbon content of imports from China at $\$ 40,50,60 / \mathrm{tCO}_{2}$ from 2020 to 2030 [38,59]. A carbon tax and an export subsidy are response policies to the U.S. carbon tariff, so there are two kinds of policy combinations as follow. (2) Tax policy combination. Scenarios 2-1 to 2-9 assume that a carbon tax is levied in China and a carbon tariff is implemented by the USA. For example, in Scenario 2-1, under the principle of the UN Model Double Taxation Convention between Developed and Developing Countries [60], if China actively levies a carbon tax at $\$ 5$, the U.S. carbon tariff rate should be reduced from $\$ 40$ to $\$ 35$. (3) Subsidy policy combination. In Scenarios 3-1 to 3-9, an export subsidy is used to reduce the cost of exports in response to the U.S. imposing carbon tariffs. For instance, in Scenario 3-1, an export subsidy 
of $\$ 5$ is provided by China's government, if the exports to the USA are levied a carbon tariff at $\$ 40$. The baseline scenario (BAU) does not include carbon tariffs.

Table 1. Scenario simulation settings.

\begin{tabular}{|c|c|c|c|c|c|c|c|}
\hline \multicolumn{2}{|c|}{ Single Carbon Tariffs Policy } & \multicolumn{3}{|c|}{ Tax Policy Combination } & \multicolumn{3}{|c|}{ Subsidy Policy Combination } \\
\hline Scenario & Carbon Tariffs & Scenario & Carbon Taxes & Carbon Tariffs & Scenario & Export Subsidies & Carbon Tariffs \\
\hline \multirow{3}{*}{$1-1$} & \multirow{3}{*}{$\$ 40$} & $2-1$ & $\$ 5$ & $\$ 35$ & $3-1$ & $\$ 5$ & $\$ 40$ \\
\hline & & $2-2$ & $\$ 10$ & $\$ 30$ & $3-2$ & $\$ 10$ & $\$ 40$ \\
\hline & & $2-3$ & $\$ 15$ & $\$ 25$ & $3-3$ & $\$ 15$ & $\$ 40$ \\
\hline \multirow{3}{*}{$1-2$} & \multirow{3}{*}{$\$ 50$} & $2-4$ & $\$ 5$ & $\$ 45$ & 3-4 & $\$ 5$ & $\$ 50$ \\
\hline & & $2-5$ & $\$ 10$ & $\$ 40$ & $3-5$ & $\$ 10$ & $\$ 50$ \\
\hline & & $2-6$ & $\$ 15$ & $\$ 35$ & $3-6$ & $\$ 15$ & $\$ 50$ \\
\hline \multirow{3}{*}{$1-3$} & \multirow{3}{*}{$\$ 60$} & $2-7$ & $\$ 5$ & $\$ 55$ & $3-7$ & $\$ 5$ & $\$ 60$ \\
\hline & & $2-8$ & $\$ 10$ & $\$ 50$ & $3-8$ & $\$ 10$ & $\$ 60$ \\
\hline & & $2-9$ & $\$ 15$ & $\$ 45$ & $3-9$ & $\$ 15$ & $\$ 60$ \\
\hline
\end{tabular}

\subsection{Trade Structure}

To better understand the impacts of policies on China's trade structure, we incorporate three terms of regional export structure, commodity export structure, and foreign trade dependence into our analysis.

\subsubsection{Regional Export Structure}

Regional export structure is the proportion of China's total exports to the USA, JAP, EU, and ROW. The three policies promote a diversion of China's exports to other countries and regions instead of the USA. The degree of "trade diversion" increases with the carbon tariff rate. However, the impact of these three policies on China's regional export structure differs over time.

The impact of $\$ 50$ carbon tariffs levied by the USA on China's regional export structure can be found in the Table A1 in Appendix A. For example, the proportion of exports from the oil and nuclear fuel processing industry to the USA drops by $32 \%$ in 2020, declining to $15 \%$ in 2030. Trade diversion is not evident in non-export-oriented sectors. Exports to JAP, EU, and ROW are unchanged due to weaker elasticity of demand for such goods in JAP, EU, and ROW. The global demand for goods, such as from coal mining and selection and the oil exploitation industry, is more inelastic. Overall, the net impact of a carbon tariff is to reduce China's trade balance. When the carbon tariff rate increases from $\$ 40$ to $\$ 60$, the influence on China's regional export structure is more obvious.

An increase in the carbon tax rate leads to a stepwise reduction in the proportion of exports to the USA. It is worth noting that the decrease in machinery and equipment manufacturing exports to the USA arises because of high-energy and high-pollution content. Exports of most commodities to other countries and regions increase under the carbon tax regime. When the carbon tax rate is fixed, raising the carbon tariff rate has a greater impact on China's regional export structure, promoting trade diversion than a carbon tax. However, a domestic carbon tax reduces the impact of a carbon tariff on China's regional export structure.

If China were to implement a subsidy rate at $\$ 5$ and the US increased the carbon tariff rate from $\$ 40$ to $\$ 60$, the regional export structure will change dramatically. If the carbon tariff is fixed, then raising the rate of export subsidy will weaken trade diversion. Compared with single carbon tariffs policy, subsidy policy combination will have a more obvious impact in the early stage of a carbon tariff implementation. However, in the long-term, the effects of subsidy policy combination and tax policy combination on China's regional export structure are similar, because carbon tariffs play a dominant economic role.

\subsubsection{Commodity Export Structure}

Commodity export structure is the proportion of different commodity exports among the total exports. For example, if we set the carbon tariff at $\$ 50$ (Figure 2a) we find a downward trend in 
the proportion of exports from coal mining and selection; machinery and equipment manufacturing; and communications. The main reason is that these sectors are energy intensive. A carbon tariff has a greater impact on primary industries because of higher elasticity of demand and a high proportion exported to the USA. When raising the rate from $\$ 40$ to $\$ 60$, a carbon tariff will have a more evident impact on China's commodity export structure involving more sectors, including the textile and products industry; wood-processing, paper, and printing industry; and transportation, storage, and post. A carbon tariff is expected to change China's commodity export structure and the degree of influence is positively correlated with the rate.

The proportions of most commodity exports decline in all tax policy combination scenarios. Compared with the single carbon tariffs, taking Scenarios 2-4, 2-5, and 2-6 as examples (Figure 2b), tax policy combination is more effective in influencing exports. For example, a carbon tax reduces the adverse effect of carbon tariffs on the mining industry, chemical industry and metal smelting industry. A carbon tax increases domestic commodity production costs, especially for energy intensive goods, causing a reduction in production and export. Furthermore, when the carbon tax rate is $\$ 5$ or $\$ 10$, raising the carbon tariff rate will decrease some exports; but, when the rate is $\$ 15$, raising carbon tariffs will not influence on China's commodity export structure. However, in Scenarios 2-4, 2-5, and 2-6, it can be found that the higher of the carbon tax rate, the more obvious changes in China's commodity export structure. In general, a carbon tax reduces the impact of carbon tariffs on China's export structure.

Combining a carbon tariff imposed by the US with a subsidy implemented by China, in response, results in a similar trend in commodity export structure. In Scenarios 3-4, 3-5, 3-6 (Figure 2c), when the carbon tariff rate is fixed at $\$ 50$, increasing the export subsidy will reduce the range of China's commodity export structure in 2030. Compared with tax policy combination, subsidy policy combination only has less impact on minority sectors. Generally, the export subsidy policy eases the impact of carbon tariffs, but does not result in an adjustment to commodity exports.

In the three fiscal policy scenarios, the production and exports of energy intensive sectors, such as machinery and equipment manufacturing and communications, decrease obviously, whereas the magnitude of changes in sectors such as other services and clean energy is slight. Environmental policies result in a great loss for energy-intensive sectors. 

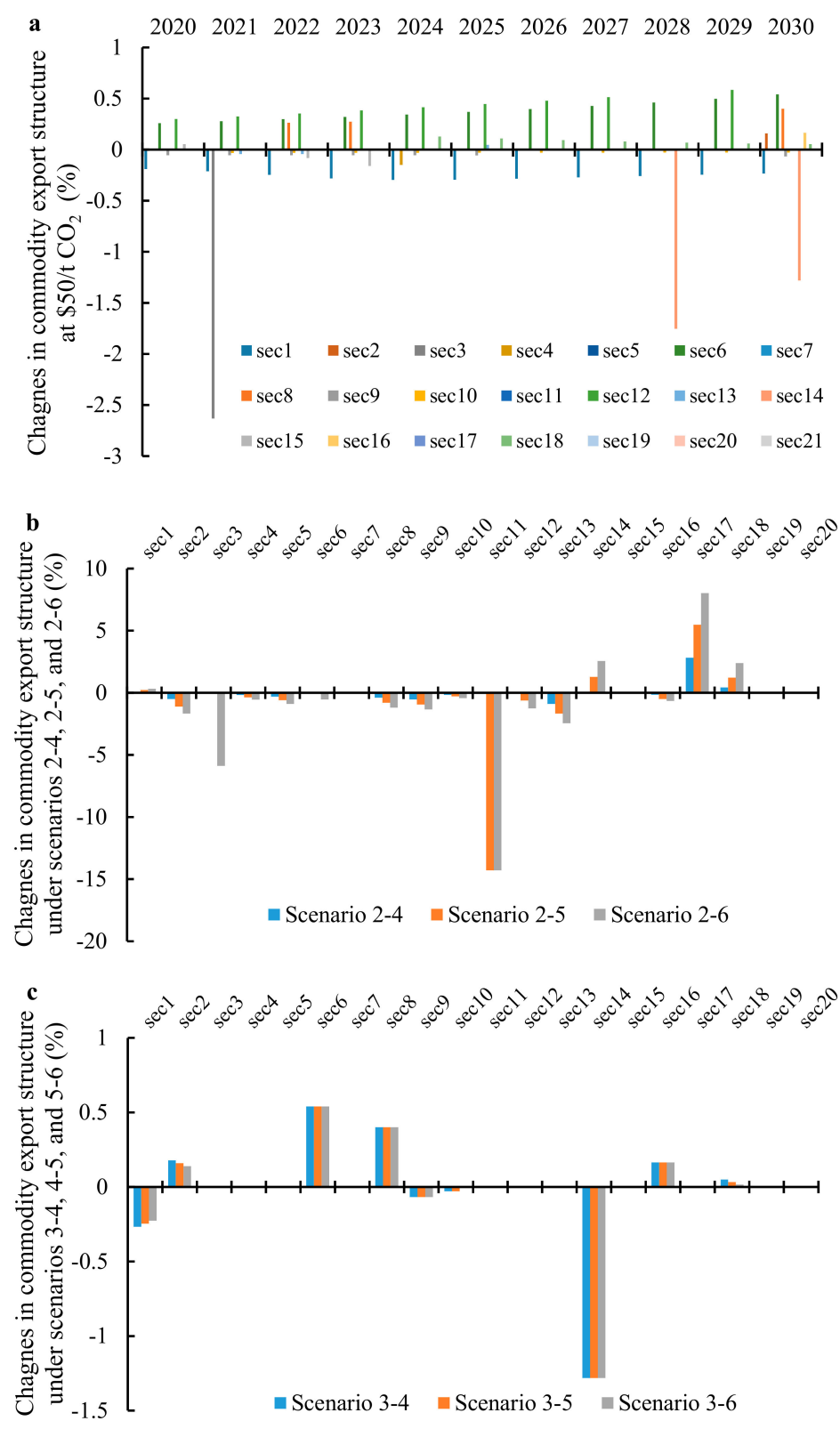

Figure 2. Impacts of various scenarios on China's commodity export structure compared to the baseline scenario (BAU). (a-c) Changes in commodity export structure at the U.S. carbon tariffs $\$ 50 / \mathrm{t} \mathrm{CO}_{2}$ from 2020 to 2030 (a); under the tax policy combination (Scenarios 2-4, 2-5, and 2-6) in 2030 (b); under the subsidy policy (Scenarios 3-4, 3-5, and 3-6) in 2030 (c).

\subsubsection{Foreign Trade Dependence}

Foreign trade dependence is the proportion of export and import values relative to GDP. Export dependence is the proportion of export value relative to GDP. As shown in Figure 3a-c, the trends in foreign trade dependence are similar for the single carbon tariffs and subsidy policy combination. However, subsidy policy combination has a lower effect on foreign trade dependence and export dependence than the single carbon tariffs because an export subsidy reduces the impact of carbon tariffs and compensates for the trade loss caused by carbon tariffs.

Foreign trade dependence and export dependence decline dramatically by levying a carbon tax during the initial period (2020-2023), increasing slightly in 2026 and then declining through 2030. This is due to the following. The initial carbon tax will increase production costs, resulting in an adjustment to output structure and gains in productivity. A carbon tax and a carbon tariff increase 
export costs resulting in a reduction in exports. Compared with Scenarios 2-1, 2-4, and 2-7; Scenarios 2-2, 2-5, and 2-8; or Scenarios 2-3, 2-6, and 2-9 show that when the carbon tax rate is fixed, increasing the carbon tariff increases China's foreign trade and export dependence because carbon tariffs play a more prominent role in reducing GDP. Compared with the single carbon tariffs (Figure 3a), tax policy combination shows a very different trend. The main reason is that a carbon tax plays a predominant role in China's trade, and even trade diversion cannot make up for the trade loss caused by the decline exports to the USA.

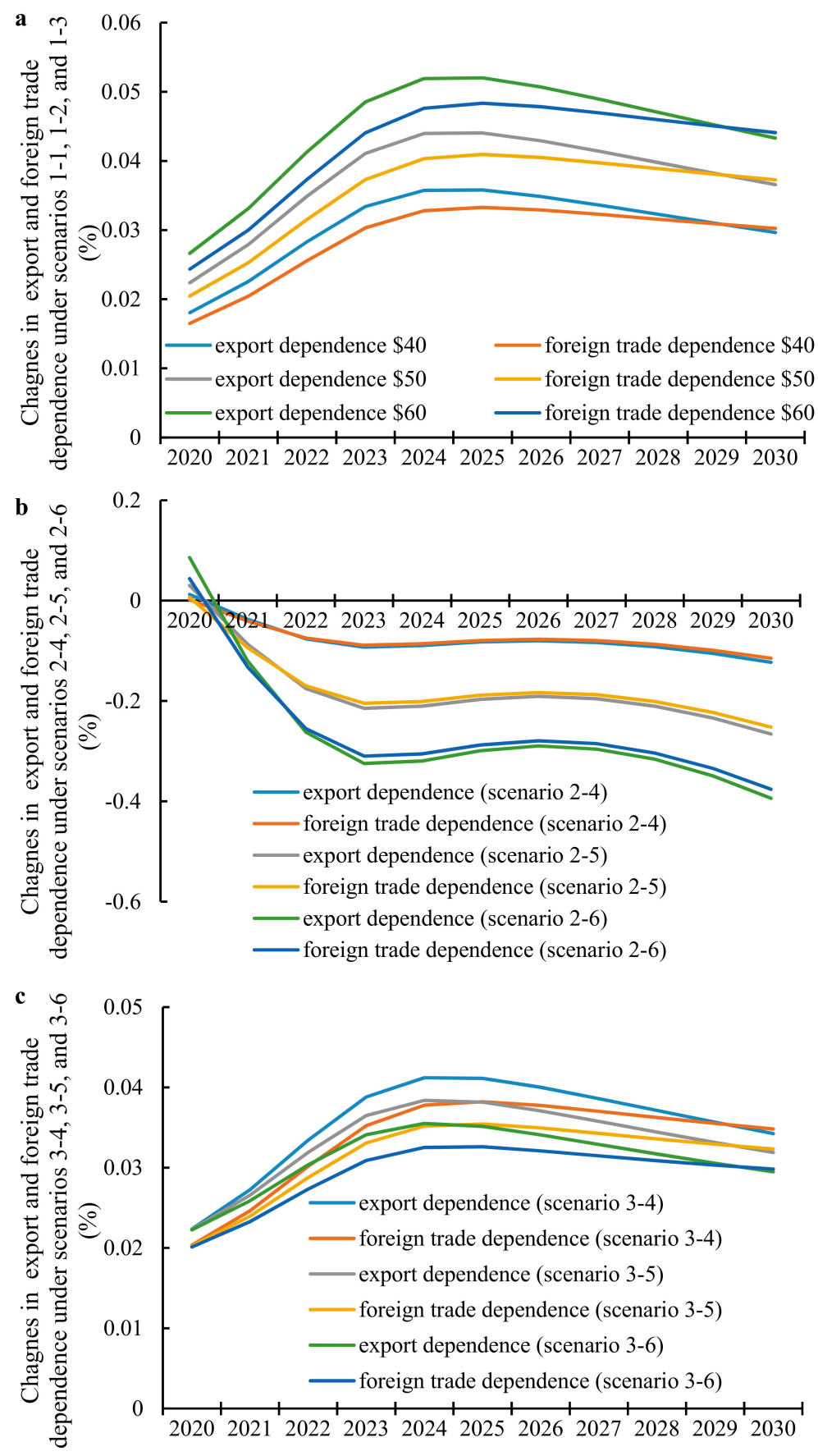

Figure 3. Changes in China's export dependence and foreign trade dependence between 2020 and 2030 under the U.S. carbon tariffs scenarios (a); tax policy combination: Scenarios 2-4, 2-5, and 2-6 (b); and subsidy policy combination: Scenarios 3-4, 3-5, and 3-6 (c) compared to BAU. 


\subsection{Carbon Emissions}

As shown in Figure $4 \mathrm{a}-\mathrm{c}$, all simulations result in lower carbon emissions, but there are big differences in the degree of change. Additionally, the initial change of carbon intensity is negative, but there is a positive change in later periods, as is the case for all schemes.
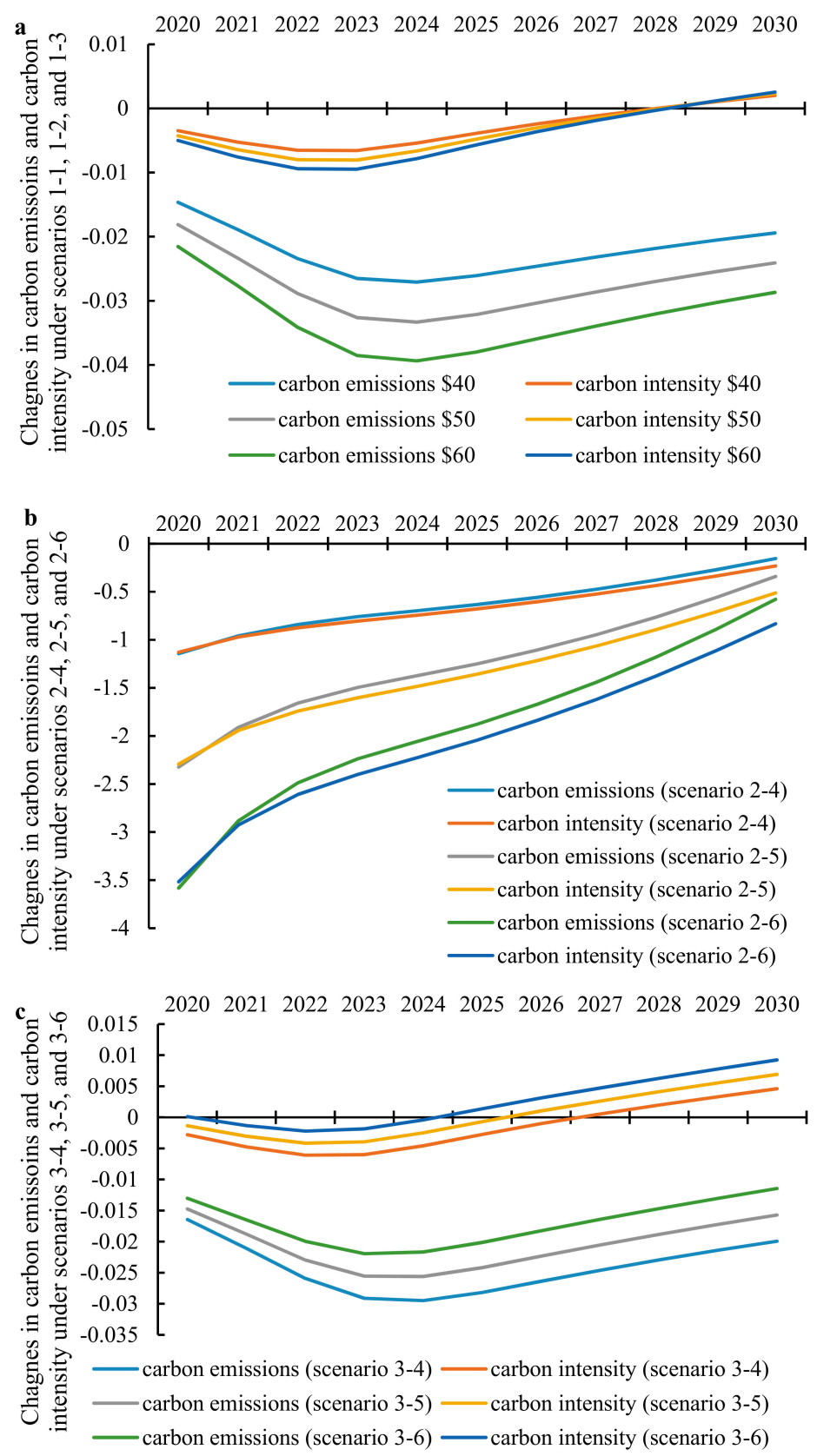

Figure 4. Changes in China's carbon intensity and carbon emissions between 2020 and 2030 under the U.S. carbon tariffs scenarios (a); tax policy combination: Scenarios 2-4, 2-5, and 2-6 (b); subsidy policy combination: Scenarios 3-4, 3-5, and 3-6 (c) compared to BAU.

Figure $4 \mathrm{a}$ shows that higher single carbon tariffs result in lower carbon emissions and carbon intensity. Figure $4 \mathrm{~b}$ shows similar results for tax policy combination although the magnitude decreases year by year. The reasons are as follows. Under the double pressure of a carbon tax and a carbon tariff, enterprises adjust their energy consumption reducing the share of gas and coal and increasing their use of clean energy. Enterprises will also increase energy efficiency, reducing energy 
consumption and the production of high-pollution goods. Improvements in production efficiency result in a rebound effect that leads to more energy consumption. In addition, compared with Scenarios 2-1, 2-4, and 2-7; Scenarios 2-2, 2-5, and 2-8; and Scenarios 2-3, 2-6, and 2-9, we find that when the carbon tax is fixed, the increase of carbon tariffs will have no obvious effect on reducing carbon emissions and carbon intensity. A carbon tax is more effective in reducing emissions than a carbon tariff.

Figure $4 \mathrm{c}$ shows that subsidy policy combination will reduce carbon emissions, but the reductions decrease year after year, and the effect on carbon intensity is not obvious. This policy is inferior to the other two policies. The subsidy policy is not conducive to reducing carbon intensity, but has a similar trend with single carbon tariffs policy. The effect of tax policy combination on reducing carbon emissions and carbon intensity is superior to subsidy policy combination.

The decrease in carbon emissions for each scenario attributes to the improvement of energy structure. As shown in Figure 5a, the proportion of coal utilization decreases during 2020 to 2030. A carbon tariff influences China's energy structure and impacts fossil fuels to a greater degree, particularly as the tax rate increases.
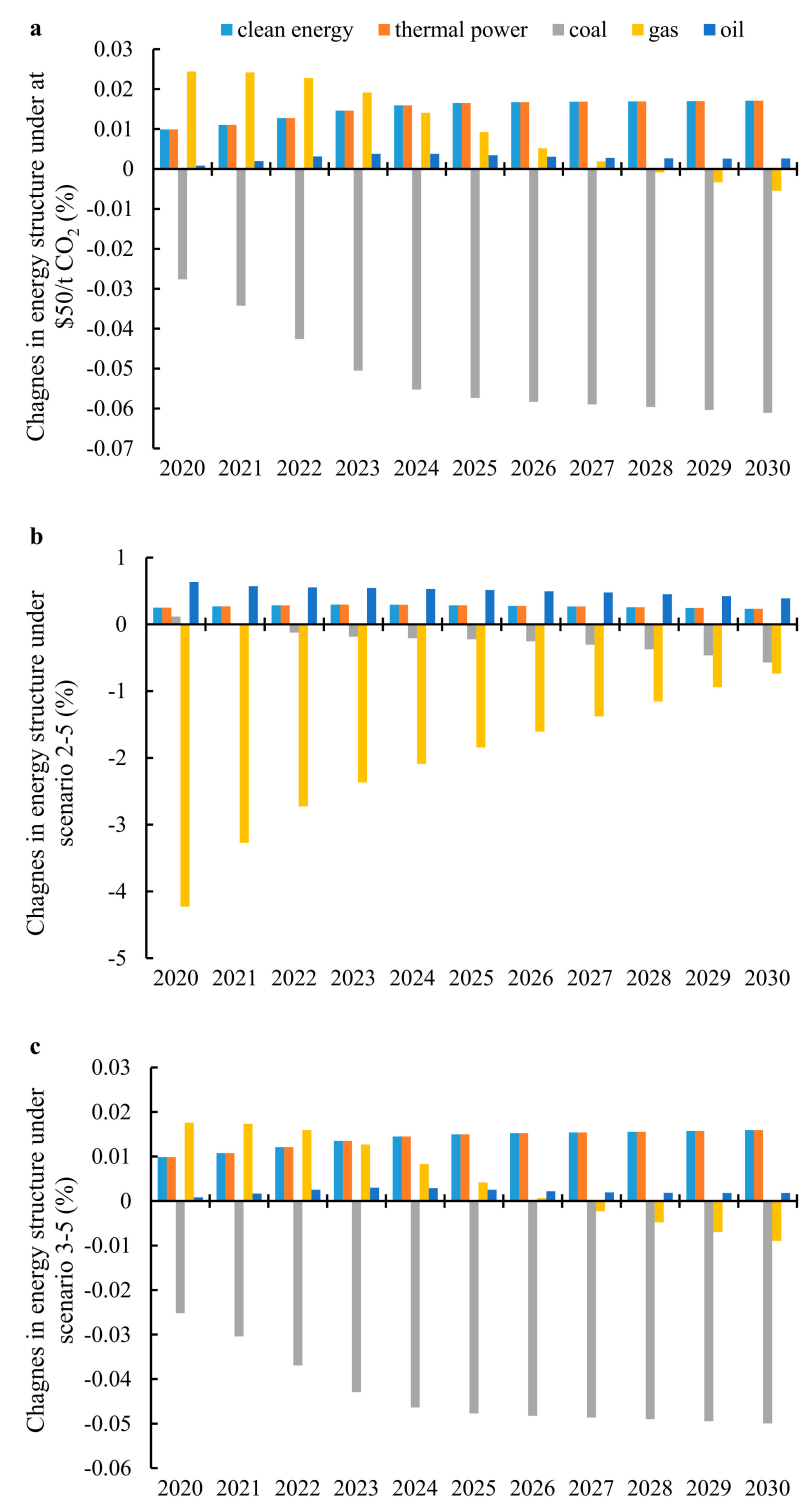

Figure 5. Changes in China's energy structure between 2020 and 2030 at the U.S. carbon tariffs of $\$ 50 / \mathrm{t} \mathrm{CO} 2$ (a): under tax policy combination of Scenarios 2-5 (b) and subsidy policy combination of Scenarios 3-5 (c) compared to BAU. 
Tax policy combination will bring about great changes in China's energy structure. Figure $5 \mathrm{~b}$ shows a decrease in the proportion of gas and coal consumption. On the other hand, changes in oil, thermal power and clean energy shares increase, but the rising trend of oil will decline over later years, and a change in clean power share will increase. Compared with single carbon tariffs policy, the tax policy combination markedly reduces the share of coal. Furthermore, compared with Scenarios 2-1, 2-4, and 2-7; Scenarios 2-2, 2-5, and 2-8; and Scenarios 2-3, 2-6, and 2-9, we find that when the carbon tax rate is fixed at $\$ 5$ or $\$ 10$, the increase in carbon tariffs reduces the proportion of all energy consumption. When the carbon tax rate increases to $\$ 15$, increasing the carbon tariff rate will not improve energy structure, confirming the dominant role of a carbon tax in reducing fossil fuel consumption.

Figure $5 c$ shows that changes in energy structure influenced by subsidy policy combination exhibit similar trends to those associated with the single carbon tariffs, but there will be differences in the range of changes, especially in the proportion of coal consumption. When the carbon tariff rate is fixed, the change of energy structure will decrease with the increase in the rate of export subsidy. Compared with Scenarios 3-1, 3-4, and 3-7; Scenarios 3-2, 3-5, and 3-8; and Scenarios 3-3, 3-6, and 3-9, we found that raising the carbon tariff rate would improve energy structure, but an export subsidy reduces the effect.

\subsection{Social Welfare}

As shown in Figure $6 a-c$, the changes in these three kinds of simulation schemes have a similar impact on welfare. A carbon tariff reduces commodity consumption and decreases welfare level dramatically. However, in the long-term, the adverse effect of a carbon tariff will slow down over time and recover. This is because Chinese enterprises will optimize their production by adjusting the structure of energy consumption, improve production efficiency, and price changes stabilize. In terms of impacts on China's energy prices, the domestic carbon tax is most obvious, so the changes in social welfare in the early stage will be greatest. Implementing an export subsidy policy in the short term will reduce the adverse impact of a carbon tariff on social welfare, but in the long-term the policy has little effect. Generally, subsidy policy combination is superior to single carbon tariffs policy, but inferior to the tax policy.

In Scenarios 1-1, 1-2, and 1-3, we find that a single carbon tariff reduces the level of social welfare, and the reduction increases with the carbon tariff rate. Comparing Scenarios 2-1, 2-4, and 2-7; Scenarios 2-2, 2-5, and 2-8; Scenarios 2-3, 2-6, and 2-9, when the carbon tax rate is fixed at $\$ 5$ or $\$ 10$, raising the carbon tariff rate will reduce welfare, but when the rate is fixed at $\$ 15$, the welfare level is relatively stable. It shows that China can levy an appropriate carbon tax, increasing fiscal revenue at the same time. If this income can be used rationally, it would improve social welfare. Comparison of Scenarios 3-1, 3-2, and 3-3; Scenarios 3-4, 3-5, and 3-6; or Scenarios 3-7, 3-8, and 3-9, we can find that, under the same carbon tariff rate level, the impact of increasing export subsidy rates on China's welfare level is smaller. 
$\mathbf{a}$

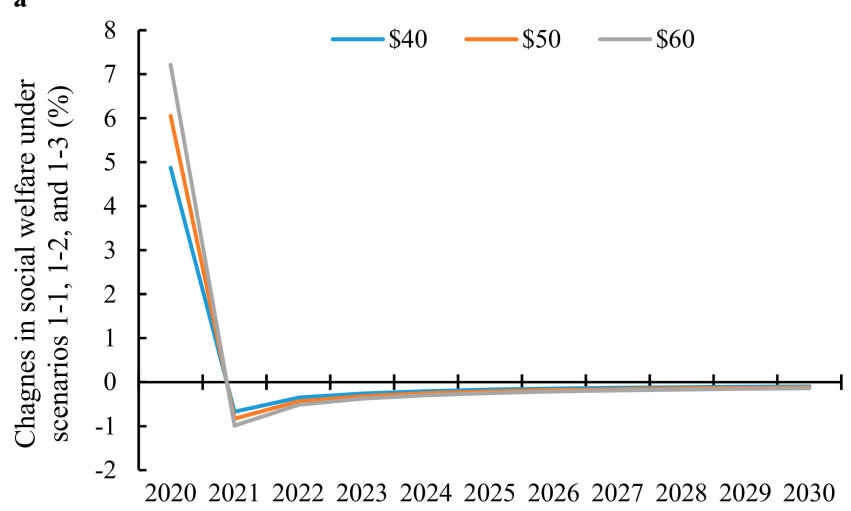

b

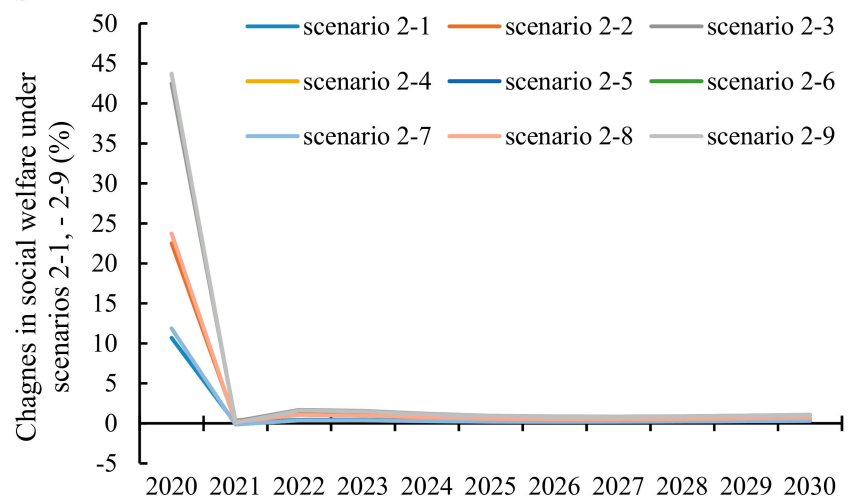

c

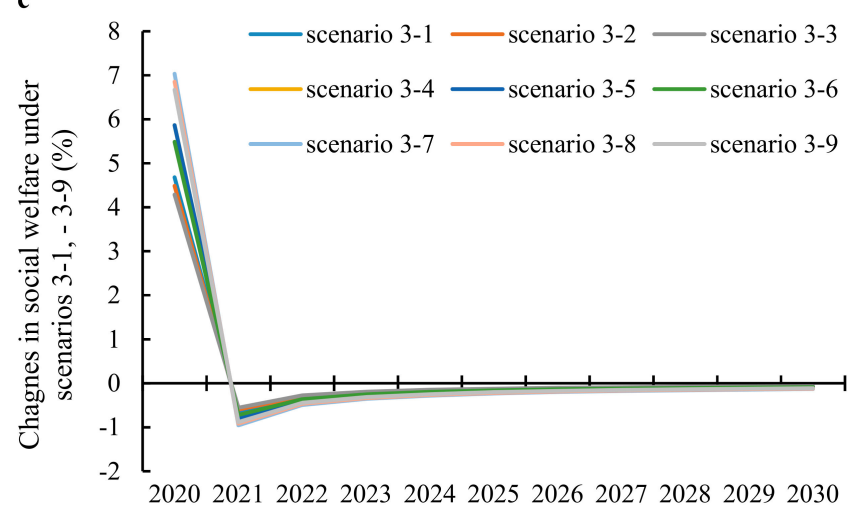

Figure 6. Changes in China's welfare between 2020 and 2030 under the U.S. carbon tariffs scenarios (a); tax policy combination scenarios (b) and subsidy policy combination scenarios (c) compared to BAU.

\section{Discussion}

Single carbon tariffs will have a great influence on China's regional export structure and commodity export structure and increase the degree of dependence on trade. The tax rate has a direct impact on China's trade structure leading to price fluctuations in the international market. When the carbon tariff rate is $\$ 50$, the price of most goods in the international market will show a downward trend, but the decrease declines over years. The reasons are as follows. The cost of exports to the USA will increase, demand in the USA drops, and the equilibrium price of the international market will decline, which will cause a reduction in revenue from exports. Trade diversion will tend to flatten out prices during later periods, a result that is consistent with the conclusions of $\mathrm{Xu}$ et al. [48]. However, a carbon tariff will lead to a drop in China's exports to the USA that is not equivalent to the growth in exports elsewhere. Carbon tariffs will have a greater impact on commodity exports. Export shares of high-energy and high-pollution goods will decline over time. 
The carbon tariff imposed by the USA will increase China's foreign trade dependence and export dependence. Figure 7 shows that carbon tariffs will reduce China's exports scale, whereas the impact of carbon tariffs on China's GDP will be even more obvious. This is mainly because the decline in export prices will affect China's economy from the perspective of supply and demand. First, the decline of export prices will lead to a decrease in export interest, leading to a lack of export power, and then goods will be transferred to the domestic market, namely, the supply side has an alternative effect; second, a carbon tariff will lead to a drop in export prices, as well as a decline in China's domestic income and a lack of demand power, namely, the demand side generates income effects. Increases in the carbon tariff rate contribute to a more pronounced adverse effect on the domestic economy.

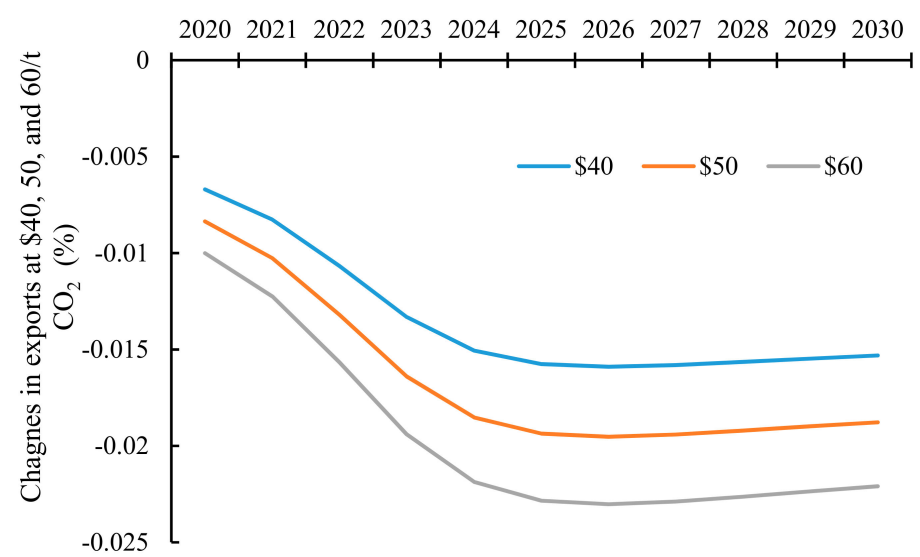

Figure 7. Impacts of the U.S. carbon tariffs on China's exports.

Tax policy combination improves China's regional export structure and commodity export structure, decreasing China's foreign trade dependence and export dependence. Trade diversion is still evident with scenarios of tax policy combinations. With the higher domestic carbon tax rate, the carbon content of China's export commodities is reduced, mitigating the impact of carbon tariffs on regional export structure. The domestic carbon tax is expected to decrease output and export shares of high-carbon sectors. A carbon tax and a carbon tariff combine to increase export costs. When the domestic carbon tax is fixed, increasing the carbon tariff results in a downward trend in China's commodity export structure. Tax policy combination inhibits the growth of foreign trade dependence and export dependence because the carbon tax increases production costs and enterprises adjust their energy structure and output structure accordingly.

The subsidy policy reduces the impacts of a carbon tariff on China's trade structure. Trade diversion occurs because the carbon tariff rate is higher than the export subsidy. Thus, carbon tariffs operating within subsidy policy combination result in trends similar to those associated with the single carbon tariffs. The export subsidy reduces the impact on carbon intensive industry and increases foreign trade and export. The export subsidy alleviates the impact of carbon tariffs on the international market, reduces trade shocks, and to a degree makes up the trade loss caused by carbon tariffs. Therefore, an export subsidy contributes to stabilizing China's trade development in the presence of a carbon tariff.

Compared with the single carbon tariffs policy, tax policy combination results in energy substitution more effectively, due to a pronounced impact on energy price as reported by Rivers and Schaufele [61]. Raising the carbon tax leads to a decline in output in most sectors, including high export sectors, sectors providing raw material or services, and high-energy consumption and high pollution sectors.

Although subsidy policy combination to a certain extent changes the structure of China's energy consumption, compared with single carbon tariffs policy and tax policy combination, the effect is weakest. First, it indicates that the export subsidy policy would reduce the effects of carbon tariffs on China's energy structure. However, the export subsidy policy does not contribute to gains in energy 
efficiency, emission reduction and output adjustments in the long-term. Moreover, it also increases government expenditure and contributes to lower welfare. However, there might be merits associated with the strategic implementation of export subsidies to some sectors [62].

The single carbon tariffs policy reduces China's carbon emissions and carbon intensity. For a long time, China's coal consumption ratio has always been high, and the proportion of fossil energy (coal, oil and natural gas) consumption has remained at $\sim 70 \%$. Compared with other fossil energy, coal has the largest carbon emission factor. Therefore, reducing coal consumption plays a key role in reducing carbon emissions. However, at $\$ 60$ a carbon tariff will have little effect on reducing carbon intensity and carbon emissions, a result that is consistent with Bao et al. [59] and Dong et al. [41]. Tax policy combination reduces the growth of China's carbon emissions and carbon intensity more effectively than carbon tariffs operating in isolation $[43,44]$. The incentives associated with a carbon tax and a carbon tariff encourages enterprises to adjust their energy consumption, increase energy efficiency, and reduce high-energy consumption and high-pollution production. A carbon tax is more effective in reducing carbon emissions because it directly targets carbon in the economy. However, imposing a carbon tariff on exports could act as an incentive for China to implement a carbon tax. Pricing carbon through taxes or trading permits is an important instrument to slow climate change. International coordination around carbon prices has been on the table for years [63-66]. Although 20\% of carbon emissions are priced over 57 jurisdictions according to World Bank [67], these prices are much lower than the cost to society. Nordhaus [68] examined the climate club approach for international climate policy using the C-DICE economic model. The results show that sanctions against nonparticipants can effectively push them to join a group to reduce greenhouse gas emissions, which is to some extent consistent with the implication from the U.S. carbon tariffs in this study. The export subsidy policy has little effect on the structure of China's trade, output and energy. That is mainly because enterprises' inner incentive to reduce emissions will be insufficient and their external forces to cut emissions will also be weakened.

Single carbon tariffs policy reduces China's social welfare, which is consistent with Ghosh et al. [69] and Li et al. [8]. According to Hicks equivalence, the level of social welfare in China decreases dramatically due to lower household income and consumption. The single carbon tariffs policy impacts production and sales resulting in lower levels of employment. In contrast, our result shows that a domestic carbon tax is of benefit because it reduces the loss caused by carbon tariffs to China's social welfare, which is consistent with the Dong [41]. In addition, a carbon tax increases government revenue. If this revenue is used rationally, it could improve social welfare [70,71]. We show that the export subsidy policy could alleviate the adverse impact of a carbon tariff on social welfare in the short-run, but in the long-run the policy will be inferior to a carbon tax. Clearly, the export subsidy policy will increase the government expenditure.

To comprehensively evaluate these environmental policies, the stakeholders' different preferences should be taken into account. Nesticò and Sica [72] built an economic evaluation model which is defined for the optimal selection of urban development projects. This model benefits to make a reasonable decision on behalf of both a public and a private nature. The model used in this study needs more improvement by considering the stakeholders' different preferences.

\section{Conclusions and Policy Implications}

We use a recursive multisector DCGE model to examine the effects of three policies: single carbon tariffs policy, tax policy combination, and subsidy policy combination. Twenty-one simulations to illustrate the long-term changes of China's economic structure, carbon emissions, and social welfare from 2020 to 2030.

First, all policies promote trade diversion and impact trade structure. However, a domestic carbon tax alleviates the impact of a carbon tariff on China's regional export structure. We show that tax policy combination reduces the proportion energy-intensive exports, improves China's commodity export structure, and reduces foreign trade and export dependence. However, a carbon tax reduces the 
opportunity for China to develop new markets outside the USA. Subsidy policy combination directly reduces the effects of carbon tariffs by lowering tax rates. However, the impact of subsidy policy combination on China's export trade structure is similar to single carbon tariffs policy, but its influence is weaker than single carbon tariffs policy and tax policy combination.

Second, all of the policies improve China's energy structure by reducing the proportion of coal consumption and increasing the proportion of clean power consumption through the price mechanism. Tax policy combination is most obvious, followed by single carbon tariffs policy, and subsidy policy combination.

Third, a carbon tariff is an effective measure to reduce carbon emissions, and has a negative impact on social welfare. The impact of carbon tariffs on decreasing China's carbon emissions and carbon intensity is inferior to a domestic carbon tax. To some extent, the export subsidy policy could weaken the effects of a carbon tariff. It also stabilizes social welfare in the early stage of carbon tariffs, but its long-term effect is not as good as a carbon tax.

We offer the following policy recommendations. First, the gains in trade diversion from the implementation of carbon tariffs are not equivalent to trade losses. Strengthening China-US trade dependency is not conducive to the development of China's multilateral trade. Therefore, China should focus on advancing multilateral trade. A domestic carbon tax could work to avoid or partially offset the imposition of foreign carbon tariffs and reduce economic losses caused by carbon tariffs. Given the unreasonableness of China's commodity export structure and output structure, government should implement policy and funding to support the development of low carbon sectors.

Second, carbon tariffs will change China's energy structure, but they are not effective in reducing emissions. Therefore, China should adhere to the path of low carbon development, promote scientific and technological innovation, increase the development and support of new energy and encourage use of clean energy. Increasing the share of clean energy in total energy consumption can reverse the risk of energy shortage, improving the energy structure and output structure. Policy could embrace and encourage research investment, technological innovation, and industry-university-research cooperation. Formulating sound and reasonable policy combinations, especially in the face of carbon tariffs, including a carbon tax, carbon emissions trading schemes, and improving energy efficiency, could result in a "double dividend".

If the aim is to reduce emissions then a carbon tax is more effective than a carbon tariff. A carbon tax would signal China's commitment to climate targets, improve international competitiveness, and better position itself within international markets. Lower emissions would also lower costs associated with pollution in densely populated areas. From a practical point of view, governments could pay more attention to the development of emission reduction technologies, like implementing subsidy policy for R\&D [47] and promoting corporate emission reduction behavior, which contribute to achieving emission reduction targets and improving the international competitiveness of enterprises.

Third, carbon tariffs reduce social welfare, and government should carefully consider its response to mitigate the adverse effect. An export subsidy is one possible response to imposition of a carbon tariff. This may assist dampen the adverse impact on welfare in the short-run. However, given that environmental quality is a normal good it is likely that a carbon tax policy, comprising an exogenous tariff imposed by the US and a carbon tax, work together to improve social welfare.

Author Contributions: W.Z., Writing-original draft preparation, Methodology and software; S.X., Conceptualization, formal analysis and Writing-review and editing; Z.H., Validation and Writing-review and editing; B.S., Investigation and Resources; B.Z., Validation and Data curation; S.W., Data curation.

Acknowledgments: This study was financially supported by the National Natural Science Foundation of China (No. 71573253; 71974083), the Ministry of Education Humanities and Social Sciences Planning Fund (No. 19YJA790024), Jiangsu Social Science Fund (No. 18EYB014), the National Key Research and Development Program of the Ministry of Science and Technology of China (No. 2017YFC0213005), and the China Scholarship Council (No. 201706420071).

Conflicts of Interest: The authors declare no conflict of interest. 


\section{Appendix A}

Table A1. Impacts of the U.S. carbon tariffs on China's regional export structure (\%) at \$50/t $\mathrm{CO}_{2}$ from 2020 to 2030.

\begin{tabular}{|c|c|c|c|c|c|c|c|c|c|c|c|c|c|c|c|}
\hline Sector & Region & 2020 & 2022 & 2024 & 2026 & 2028 & 2030 & Sector & Region & 2020 & 2022 & 2024 & 2026 & 2028 & 2030 \\
\hline \multirow{4}{*}{ sector1 } & USA & -0.6443 & -0.6443 & -0.6443 & -0.7732 & -0.7732 & -0.7732 & \multirow{4}{*}{ sector 11} & USA & -0.2252 & -0.2252 & -0.2252 & -0.2252 & -0.2252 & -0.2252 \\
\hline & JAP & 0.0729 & 0.0729 & 0.0729 & 0.0729 & 0.0729 & 0.0729 & & JAP & 0.0000 & 0.0000 & 0.0000 & 0.0000 & 0.0000 & 0.0000 \\
\hline & EU & 0.0000 & 0.0000 & 0.0000 & 0.0000 & 0.0606 & 0.0606 & & EU & 0.0000 & 0.0000 & 0.0000 & 0.0000 & 0.0000 & 0.0000 \\
\hline & ROW & 0.0484 & 0.0645 & 0.0645 & 0.0645 & 0.0645 & 0.0645 & & ROW & 0.0000 & 0.0000 & 0.0000 & 0.0000 & 0.0000 & 0.0000 \\
\hline \multirow{4}{*}{ sector 2} & USA & -0.6774 & -0.6774 & -0.6774 & -0.6774 & -0.6774 & -0.6774 & \multirow{4}{*}{ sector 12} & USA & -1.8198 & -1.8198 & -1.7331 & -1.7331 & -1.6464 & -1.6464 \\
\hline & JAP & 0.0655 & 0.0655 & 0.0655 & 0.0655 & 0.0655 & 0.0655 & & JAP & 0.2471 & 0.2471 & 0.2471 & 0.2471 & 0.2471 & 0.2471 \\
\hline & EU & 0.0892 & 0.0892 & 0.0892 & 0.0892 & 0.0892 & 0.0892 & & EU & 0.2349 & 0.2349 & 0.2349 & 0.2349 & 0.2349 & 0.2055 \\
\hline & ROW & 0.0990 & 0.0990 & 0.0990 & 0.0990 & 0.0990 & 0.0990 & & ROW & 0.2604 & 0.2604 & 0.2367 & 0.2367 & 0.2367 & 0.2367 \\
\hline \multirow{4}{*}{ sector 3} & USA & -0.0652 & -0.0652 & -0.0652 & -0.0652 & -0.0652 & -0.0652 & \multirow{4}{*}{ sector 13} & USA & -0.1092 & -0.1092 & -0.1092 & -0.1092 & -0.1092 & -0.0546 \\
\hline & JAP & 0.0000 & 0.0000 & 0.0000 & 0.0000 & 0.0000 & 0.0000 & & JAP & 0.0000 & 0.0000 & 0.0000 & 0.0000 & 0.0000 & 0.0000 \\
\hline & $\mathrm{EU}$ & 0.0000 & 0.0000 & 0.0000 & 0.0000 & 0.0000 & 0.0000 & & EU & 0.0353 & 0.0353 & 0.0353 & 0.0353 & 0.0353 & 0.0353 \\
\hline & ROW & 0.0000 & 0.0000 & 0.0000 & 0.0000 & 0.0000 & 0.0000 & & ROW & 0.0219 & 0.0219 & 0.0219 & 0.0219 & 0.0219 & 0.0219 \\
\hline \multirow{4}{*}{ sector 4} & USA & 0.0000 & 0.0000 & 0.0000 & 0.0000 & 0.0000 & 0.0000 & \multirow{4}{*}{ sector 14} & USA & 0.0000 & 0.0000 & 0.0000 & 0.0000 & 0.0000 & 0.0000 \\
\hline & JAP & 0.0000 & 0.0000 & 0.0000 & 0.0000 & 0.0000 & 0.0000 & & JAP & 0.0000 & 0.0000 & 0.0000 & 0.0000 & 0.0000 & 0.0000 \\
\hline & $\mathrm{EU}$ & 0.0000 & 0.0000 & 0.0000 & 0.0000 & 0.0000 & 0.0000 & & EU & 0.0000 & 0.0000 & 0.0000 & 0.0000 & 0.0000 & 0.0000 \\
\hline & ROW & 0.0209 & 0.0209 & 0.0209 & 0.0000 & 0.0000 & 0.0000 & & ROW & 0.0000 & 0.0000 & 0.0000 & 0.0000 & 0.0000 & 0.0000 \\
\hline \multirow{4}{*}{ sector 5} & USA & -0.0613 & -0.0613 & -0.0613 & -0.0613 & -0.0306 & -0.0306 & \multirow{4}{*}{ sector 15} & USA & -5.3691 & -4.3624 & -3.3557 & -2.6846 & -2.3490 & -2.0134 \\
\hline & JAP & 0.0000 & 0.0000 & 0.0000 & 0.0000 & 0.0000 & 0.0000 & & JAP & 0.1969 & 0.1969 & 0.1969 & 0.1969 & 0.1969 & 0.1969 \\
\hline & $\mathrm{EU}$ & 0.0460 & 0.0460 & 0.0460 & 0.0460 & 0.0460 & 0.0460 & & EU & 0.1235 & 0.1235 & 0.0000 & 0.0000 & 0.0000 & 0.0000 \\
\hline & ROW & 0.0268 & 0.0268 & 0.0268 & 0.0268 & 0.0268 & 0.0268 & & ROW & 0.1670 & 0.1431 & 0.1073 & 0.0835 & 0.0716 & 0.0596 \\
\hline \multirow{4}{*}{ sector 6} & USA & -1.1204 & -1.0644 & -1.0644 & -1.0084 & -0.9524 & -0.9524 & \multirow{4}{*}{ sector 16} & USA & 0.0000 & 0.0000 & 0.0000 & 0.0000 & 0.0000 & 0.0000 \\
\hline & JAP & 0.2141 & 0.2141 & 0.2141 & 0.2141 & 0.2141 & 0.2141 & & JAP & 0.0000 & 0.0000 & 0.0000 & 0.0000 & 0.0000 & 0.0000 \\
\hline & $\mathrm{EU}$ & 0.2350 & 0.2350 & 0.1763 & 0.1763 & 0.1763 & 0.1763 & & EU & 0.0000 & 0.0000 & 0.0000 & 0.0000 & 0.0000 & 0.0000 \\
\hline & ROW & 0.2509 & 0.2330 & 0.2330 & 0.2330 & 0.2151 & 0.2151 & & ROW & 0.0000 & 0.0000 & 0.0000 & 0.0000 & 0.0000 & 0.0000 \\
\hline \multirow{4}{*}{ sector 7} & USA & -0.8403 & -0.7803 & -0.7803 & -0.7203 & -0.7203 & -0.6603 & \multirow{4}{*}{ sector 17} & USA & -31.9328 & -26.0504 & -20.1681 & -17.2269 & -15.5462 & -14.7059 \\
\hline & JAP & 0.1393 & 0.1393 & 0.1393 & 0.1393 & 0.1393 & 0.1393 & & JAP & 0.6993 & 0.6993 & 0.6993 & 0.6993 & 0.0000 & 0.0000 \\
\hline & $\mathrm{EU}$ & 0.1586 & 0.1586 & 0.1586 & 0.1586 & 0.1586 & 0.1586 & & EU & 0.0000 & 0.0000 & 0.0000 & 0.0000 & 0.0000 & 0.0000 \\
\hline & ROW & 0.1747 & 0.1572 & 0.1572 & 0.1572 & 0.1398 & 0.1398 & & ROW & 0.7905 & 0.6449 & 0.4993 & 0.4265 & 0.3849 & 0.3641 \\
\hline \multirow{4}{*}{ sector 8} & USA & -0.5170 & -0.4431 & -0.4431 & -0.3693 & -0.3693 & -0.2954 & \multirow{4}{*}{ sector 18} & USA & -0.4746 & -0.6523 & -0.8445 & -1.0183 & -1.1823 & -1.3392 \\
\hline & JAP & 0.1538 & 0.1538 & 0.1538 & 0.1538 & 0.1538 & 0.1538 & & JAP & 0.0000 & 0.0000 & 0.0000 & 0.0000 & 0.0000 & 0.0000 \\
\hline & EU & 0.0569 & 0.0569 & 0.0569 & 0.0569 & 0.0569 & 0.0569 & & EU & 0.0000 & 0.0000 & 0.0000 & 0.0000 & 0.0000 & 0.0000 \\
\hline & ROW & 0.0801 & 0.0801 & 0.0641 & 0.0641 & 0.0481 & 0.0481 & & ROW & 0.0000 & 0.0000 & 0.0000 & 0.0000 & 0.0000 & 0.0000 \\
\hline \multirow{4}{*}{ sector 9} & USA & -0.0346 & -0.0346 & -0.0346 & -0.0346 & -0.0346 & -0.0346 & \multirow{4}{*}{ sector 20} & USA & -0.4762 & -0.3175 & -0.3175 & -0.1587 & -0.1587 & -0.1587 \\
\hline & JAP & 0.0000 & 0.0000 & 0.0000 & 0.0000 & 0.0000 & 0.0000 & & JAP & 0.0000 & 0.0000 & 0.0000 & 0.0000 & 0.0000 & 0.0000 \\
\hline & $\mathrm{EU}$ & 0.0461 & 0.0461 & 0.0461 & 0.0461 & 0.0461 & 0.0461 & & EU & 0.0000 & 0.0000 & 0.0000 & 0.0000 & 0.0000 & 0.0000 \\
\hline & ROW & 0.0240 & 0.0240 & 0.0240 & 0.0240 & 0.0240 & 0.0000 & & ROW & 0.0398 & 0.0265 & 0.0265 & 0.0133 & 0.0133 & 0.0133 \\
\hline \multirow{4}{*}{ sector 10} & USA & 0.0000 & 0.0000 & 0.0000 & 0.0000 & 0.0000 & 0.0000 & \multirow{4}{*}{ sector 21} & USA & -0.4762 & -0.3175 & -0.3175 & -0.1587 & -0.1587 & -0.1587 \\
\hline & JAP & 0.0000 & 0.0000 & 0.0000 & 0.0000 & 0.0000 & 0.0000 & & JAP & 0.0000 & 0.0000 & 0.0000 & 0.0000 & 0.0000 & 0.0000 \\
\hline & $\mathrm{EU}$ & 0.0000 & 0.0000 & 0.0000 & 0.0000 & 0.0000 & 0.0000 & & $\mathrm{EU}$ & 0.0000 & 0.0000 & 0.0000 & 0.0000 & 0.0000 & 0.0000 \\
\hline & ROW & 0.0000 & 0.0000 & 0.0000 & 0.0000 & 0.0000 & 0.0000 & & ROW & 0.0398 & 0.0265 & 0.0265 & 0.0133 & 0.0133 & 0.0133 \\
\hline
\end{tabular}

Notes: Some values are "0" after four digits are retained, which indicates the influence is very small [1]. Sector 19 is not displayed in the table because this sector has no foreign trade [2]. 


\section{References}

1. Congress U.S. American Clean Energy and Security Act of 2009; 111th Congress, 1st session, HR, 2454; ACEEE: Washington, DC, USA, 2009.

2. Walras, L. Elements of Pure Economics or the Theory of Social Wealth; Jaffe, W.; Kelley, A.M., Translators; Orion Editions: London, UK, 1874.

3. Rocchi, P.; Serrano, M.; Roca, J.; Arto, I. Border carbon adjustments based on avoided emissions: Addressing the challenge of its design. Ecol. Econ. 2018, 145, 126-136. [CrossRef]

4. Shen, M.Z. A new analysis on legality of carbon tariff under multilateral legal regime. J. Int. Trade 2011, 5, 149-156. (In Chinese)

5. Lin, B.Q.; Li, A.J. Is Carbon Motivated Border Tax Justifiable? Econ. Res. J. 2012, 11, 118-127. (In Chinese)

6. Dong, Y.; Walley, J. How large are the impacts of carbon motivated border tax adjustments? Clim. Chang. Econ. 2012, 3, 1250001. [CrossRef]

7. Yuan, Y. CGE model-based quantitative analysis of the impact of carbon tariffs on Chinese economy. J. Int. Trade 2013, 2, 92-99. (In Chinese)

8. Li, A.J.; Zhang, A.Z.; Cai, H.B.; Li, X.F.; Peng, S.S. How large are the impacts of carbon-motivated border tax adjustments on China and how to mitigate them? Energy Policy 2013, 63, 927-934. [CrossRef]

9. Wu, Z.H.; Wang, X.T. The influence of carbon tariff on China's industrial economy and Countermeasures. Manag. Adm. 2015, 3, 85-87. (In Chinese)

10. Majocchi, A.; Missaglia, M. Environmental Taxes and Border Tax Adjustment; Societa Italiana Economia Pubblica: Pavia, Italy, 2001.

11. Hübler, M. Carbon tariffs on Chinese exports: Emissions reduction, threat, or farce? Energy Policy 2012, 50, 315-327. [CrossRef]

12. Fischer, C.; Fox, A.K. Comparing policies to combat emissions leakage: Border carbon adjustments versus rebates. J. Environ. Econ. Manag. 2012, 64, 199-216. [CrossRef]

13. Kuik, O.; Hofkes, M. Border adjustment for European emissions trading: Competitiveness and carbon leakage. Energy Policy 2010, 38, 1741-1748. [CrossRef]

14. Xu, S.C.; Zhang, W.W. Analysis of impacts of carbon taxes on China's economy and emission reduction under different refunds: Based on dynamic CGE model. China Popul. Resour. Environ. 2016, 26, 46-54. (In Chinese)

15. Xu, S.C.; He, Z.X.; Long, R.Y.; Chen, H.; Han, H.M.; Zhang, W.W. Comparative analysis of the regional contributions to carbon emissions in China. J. Clean. Prod. 2016, 127, 406-417. [CrossRef]

16. Zhang, J.; Zhang, Y. Carbon tax, tourism $\mathrm{CO}_{2}$ emissions and economic welfare. Ann. Tour. Res. 2018, 69, 18-30. [CrossRef]

17. Wesseh, P.K., Jr.; Lin, B.; Atsagli, P. Carbon taxes, industrial production, welfare and the environment. Energy 2017, 123, 305-313. [CrossRef]

18. Wei, Z.X.; Li, W.J.; Wamg, T. The impacts and countermeasures of levying carbon tax in China under low-carbon economy. Energy Procedia 2011, 5, 1968-1973.

19. Dong, H.; Dai, H.; Geng, Y.; Fujita, T.; Liu, Z.; Xie, Y.; Wu, R.; Fujii, M.; Masui, T.; Tang, L. Exploring impact of carbon tax on China's CO2 reductions and provincial disparities. Renew. Sustain. Energy Rev. 2017, 77, 596-603. [CrossRef]

20. Lu, C.; Tong, Q.; Liu, X. The impacts of carbon tax and complementary policies on Chinese economy. Energy Policy 2010, 38, 7278-7285. [CrossRef]

21. Liu, Y.; Lu, Y. The economic impact of different carbon tax revenue recycling schemes in China: A model-based scenario analysis. Appl. Energy 2015, 141, 96-105. [CrossRef]

22. Zhang, Y.J.; Wei, Y.M. An overview of current research on EU ETS: Evidence from its operating mechanism and economic effect. Appl. Energy 2010, 87, 1804-1814. [CrossRef]

23. Zhang, M.; Liu, Z.; Jin, W.; van Dijk, M.P. Emission Trading Schemes in China and the European Union, Achievements and Challenges. Low Carbon Econ. 2018, 9, 33. [CrossRef]

24. Zhang, J.; Wang, Z.; Du, X. Lessons learned from China's regional carbon market pilots. Econ. Energy Environ. Policy 2017, 6, 19-38. [CrossRef]

25. Wang, P.; Dai, H.C.; Ren, S.Y.; Zhao, D.Q.; Masui, T. Achieving Copenhagen target through carbon emission trading: Economic impacts assessment in Guangdong Province of China. Energy 2015, 79, 212-227. [CrossRef] 
26. Martin, R.; Muûls, M.; Wagner, U.J. The impact of the European Union Emissions Trading Scheme on regulated firms: What is the evidence after ten years? Rev. Environ. Econ. Policy 2015, 10, 129-148. [CrossRef]

27. Oestreich, A.M.; Tsiakas, I. Carbon emissions and stock returns: Evidence from the EU Emissions Trading Scheme. J. Bank. Financ. 2015, 58, 294-308. [CrossRef]

28. Lin, B.; Jia, Z. What will China's carbon emission trading market affect with only electricity sector involvement? A CGE based study. Energy Econ. 2019, 78, 301-311. [CrossRef]

29. Flues, F.; Thomas, A. The Distributional Effects of Energy Taxes; OECD Taxation Working Papers No. 23; Centre for Tax Policy and Administration, Pascal Saint-Amans: Paris, France, 2015.

30. Commins, N.; Lyons, S.; Schiffbauer, M.; Tol, R.S. Climate policy \& corporate behavior. Energy J. 2011, 32, 51-68.

31. Gonseth, C.; Cadot, O.; Mathys, N.A.; Thalmann, P. Energy-tax changes and competitiveness: The role of adaptive capacity. Energy Econ. 2015, 48, 127-135. [CrossRef]

32. Rocchi, P.; Serrano, M.; Roca, J. The reform of the European energy tax directive: Exploring potential economic impacts in the EU27. Energy Policy 2014, 75, 341-353. [CrossRef]

33. Lai, C.F. Examining the double dividend effect of energy tax with the overlapping generations model. Int. J. Energy Econ. Policy 2016, 6, 53-57.

34. Zhao, H.R.; Guo, S.; Fu, L.W. Review on the costs and benefits of renewable energy power subsidy in China. Renew. Sustain. Energy Rev. 2014, 37, 538-549. [CrossRef]

35. Zhang, M.M.; Zhou, D.Q.; Zhou, P.; Chen, H.T. Optimal design of subsidy to stimulate renewable energy investments: The case of China. Renew. Sustain. Energy Rev. 2017, 71, 873-883. [CrossRef]

36. Chen, W.; Yin, H. Optimal subsidy in promoting distributed renewable energy generation based on policy benefit. Clean Technol. Environ. Policy 2017, 19, 225-233. [CrossRef]

37. Murray, B.C.; Cropper, M.L.; de la Chesnaye, F.C.; Reilly, J.M. How effective are US renewable energy subsidies in cutting greenhouse gases? Am. Econ. Rev. 2014, 104, 569-574. [CrossRef]

38. Liang, Q.M.; Wang, T.; Xue, M.M. Addressing the competitiveness effects of taxing carbon in China: Domestic tax cuts versus border tax adjustments. J. Clean. Prod. 2016, 112, 1568-1581. [CrossRef]

39. Dissou, Y.; Karnizova, L. Emissions cap or emissions tax? A multi-sector business cycle analysis. J. Environ. Econ. Manag. 2016, 79, 169-188. [CrossRef]

40. Eyland, T.; Zaccour, G. Carbon tariffs and cooperative outcomes. Energy Policy 2014, 65, 718-728. [CrossRef]

41. Dong, Y.L.; Masanobu, I.; Hagiwara, T. Economic and environmental impact analysis of carbon tariffs on Chinese exports. Energy Econ. 2015, 50, 80-95. [CrossRef]

42. Qu, R.X.; Wu, J. Study on welfare effects of carbon tariffs. China Popul. Resour. Environ. 2011, 21, 37-42. (In Chinese)

43. Zhu, A.D. Low-Carbon Policies: A Comparison of Carbon Tariff and Carbon Tax; Zhejiang University: Zhejiang, China, 2015. (In Chinese)

44. Jiang, D. A Simulation Study of China's Imposing Carbon Tax to Respond to American Catbon Tariffs; Jiangsu University: Zhenjiang, China, 2016. (In Chinese)

45. Yang, S.H.; Wei, S.D. Export subsidy or export tariff? A game analysis of trade policies and timing choices based on carbon tariff. Int. Econ. Trade Res. 2014, 30, 39-51. (In Chinese)

46. Zhan, Z. Carbon tariff, export subsidy and the international competitiveness of developing countries' enterprises: A sturdy based on Bertrand model. Int. Econ. Trade Res. 2015, 31, 54-63. (In Chinese)

47. Hou, Y.M.; Jia, M.; Chen, T.P.; Sun, C.Y.; Zhu, L.C.; Wei, P. Research on the optimal emission-abatement R\&D subsidy policy under carbon tariff. Ecol. Econ. 2016, 32, 52-58. (In Chinese)

48. Xu, S.C.; Zhang, W.W.; Gao, C.; Long, R.Y.; Chen, H. Impacts of Carbon Tariffs on China's Economic Structure and Carbon Intensity: Simulation Analysis Using a Dynamic CGE Model. Feb-Fresenius Environ. Bull. 2017, $26,4742-4756$.

49. Hosoe, N.; Gasawa, K.; Hashimoto, H. Textbook of Computable General Equilibrium Modelling: Programming and Simulations; Palgrave Macmillan: Hampshire, UK, 2010.

50. Lou, F. The Theory and Application of Chinese Economy-Energy-Environment-Tax Dynamic Computable General Equilibrium Model; China Social Sciences Press: Beijing, China, 2015. (In Chinese)

51. Change, I. P. O. C. (2006). 2006 IPCC guidelines for national greenhouse gas inventorie. Available online: http://www.ipcc-nggip.ges or jp./public/2006gl/index.html (accessed on 28 April 2013). 
52. National Bureau of Statistics of P.R. China. China Energy Statistical Yearbook 2012; China Statistics Press: Beijing, China, 2013.

53. National Bureau of Statistics of P.R. China. China Statistical Yearbook 2012; China Statistics Press: Beijing, China, 2013.

54. National Bureau of Statistics of P.R. China. China Finance Yearbook 2013; China Statistics Press: Beijing, China, 2014.

55. National Bureau of Statistics of P.R. China. China Customs Statistics Yearbook 2013; China Statistics Press: Beijing, China, 2014.

56. Wang, C. Climate Change Policy Simulation and Uncertainty Analysis: A Dynamic CGE Model of China; Tsinghua University: Beijing, China, 2003. (In Chinese)

57. Guo, Z.Q.; Zhang, X.P.; Zheng, Y.H.; Rao, R. Exploring the impacts of a carbon tax on the Chinese economy using a CGE model with a detailed disaggregation of energy sectors. Energy Econ. 2014, 45, 455-462. [CrossRef]

58. Dixon, P.B.; Rimmer, D.W. Dynamic General and Equilibrium Modelling for Forecasting and Policy: A Practical Guide and Documentation of MONASH; North-Holland Publishing Company: Amsterdam, The Netherlands, 2002.

59. Bao, Q.; Tang, L.; Zhang, Z.X.; Wang, S.Y. Impacts of border carbon adjustments on China's sectoral emissions: Simulations with a dynamic computable general equilibrium model. China Econ. Rev. 2013, 24, 77-94. [CrossRef]

60. United Nations, New York. United Nations Model Double Taxation Convention between Developed and Developing Countries. 2011. Available online: https://www.un.org/esa/ffd/wp-content/uploads/2014/09/UN_ Model_2011_Update.pdf (accessed on 25 September 2019).

61. Rivers, N.; Schaufele, B. Salience of carbon taxes in the gasoline market. J. Environ. Econ. Manag. 2015, 74, 23-36. [CrossRef]

62. Wang, M.X.; Wang, M.R.; Wang, S.Y. An analysis for the effect of carbon tariff on developing countries' economy and response. J. Syst. Sci. Math. Sci. 2011, 31, 187-196. (In Chinese)

63. Weitzman, M.L. Can negotiating a uniform carbon price help to internalize the global warming externality? J. Assoc. Environ. Resour. Econ. 2014, 1, 29-49. [CrossRef]

64. Stiglitz, J.E.; Stern, N.; Duan, M.; Edenhofer, O.; Giraud, G.; Heal, G.M.; la Rovere, E.L.; Morris, A.; Moyer, E.; Pangestu, M.; et al. Report of the High-Level Commission on Carbon Prices; International Bank for Reconstruction and Development and International Development Association/The World Bank: Washington, DC, USA, 2017.

65. Carattini, S.; Kallbekken, S.; Orlov, A. How to win public support for a global carbon tax. Nature 2019, 565, 289-291. [CrossRef]

66. Council of Economic Analysis, and German Council of Economic Experts. A Uniform Carbon Price for Europe; Council of Economic Analysis, and German Council of Economic Experts: Paris, France; Wiesbaden, Germany, 2019.

67. World Bank. State and Trends of Carbon Pricing-2019; World Bank: Washington, DC, USA, 2019.

68. Nordhaus, W. Climate clubs: Overcoming free-riding in international climate policy. Am. Econ. Rev. 2015, 105, 1339-1370. [CrossRef]

69. Ghosh, M.; Luo, D.; Siddiqui, M.S.; Zhu, Y.F. Border tax adjustments in the climate policy context: $\mathrm{CO}_{2}$ versus broad-based GHG emission targeting. Energy Econ. 2012, 34, 154-167. [CrossRef]

70. Yamazaki, A. Jobs and climate policy: Evidence from British Columbia's revenue-neutral carbon tax. J. Environ. Econ. Manag. 2017, 83, 197-216. [CrossRef]

71. Karydas, C.; Zhang, L. Green tax reform, endogenous innovation and the growth dividend. J. Environ. Econ. Manag. 2017. [CrossRef]

72. Nesticò, A.; Sica, F. The sustainability of urban renewal projects: A model for economic multi-criteria analysis. J. Prop. Invest. Financ. 2017, 35, 397-409. [CrossRef]

(C) 2019 by the authors. Licensee MDPI, Basel, Switzerland. This article is an open access article distributed under the terms and conditions of the Creative Commons Attribution (CC BY) license (http://creativecommons.org/licenses/by/4.0/). 